\title{
PENGGUNAAN LIE DETECTOR (ALAT PENDETEKSI KEBOHONGAN) DALAM PROSES PENYIDIKAN TERHADAP TINDAK PIDANA DIHUBUNGKAN DENGAN UNDANG-UNDANG NOMOR 8 TAHUN 1981 TENTANG KITAB UNDANG-UNDANG HUKUM ACARA PIDANA
}

\author{
oleh: \\ Vinca Fransisca Yusefin \\ Sri Mulyati Chalil
}

\begin{abstract}
ABSTRAK
Pasal 184 Kitab Undang-undang Hukum Acara Pidana ayat (1) menyebutkan tentang alat bukti yang sah. Lie detector sebagai sarana pendukung proses pengungkapan keterangan tersangka dalam tahap proses penyidikan guna membuat terang suatu perkara, khususnya dalam kasus pembunuhan Angeline dan kasus Pembunuhan berencana yang dilakukan Jessica Kumala Wongso. Lie detector dalam fungsinya untuk mendeteksi kebohongan dengan keakuratannya yang mencapai $90 \%$ ditambah beberapa polemik kasus yang kerap kali sulit untuk dipecahkan menyebabkan urgensi dari penggunaan alat ini semakin meningkat, khususnya dalam ruang lingkup penyidikan kasus tindak pidana. Pemeriksaan dengan menggunakan lie detector juga dilakukan terhadap tersangka kasus pembunuhan Angeline yang hasilnya meyakinkan penyidik bahwa Magriet menjadi tersangka utama. Adapun identifikasi masalah dalam penelitian ini membahas tentang apakah yang menjadi urgensi penggunaan lie detector (alat pendeteksi kebohongan) dalam tahap proses penyidikan terhadap tindak pidana pembunuhan berencana dan bagaimanakah kedudukan lie detector (alat pendeteksi kebohongan) dihubungkan dengan Undang-Undang Nomor 8 Tahun 1981 tentang Kitab Undang-Undang Hukum Acara Pidana. Penelitian ini bertujuan untuk mengetahui urgensi penggunaan lie detector (alat pendeteksi kebohongan) dalam tahap proses penyidikan terhadap tindak pidana pembunuhan berencana dan kedudukan lie detector (alat pendeteksi kebohongan) dihubungkan dengan Undang-Undang Nomor 8 Tahun 1981 tentang Kitab Undang-Undang Hukum Acara Pidana. Hasil penelitian ini adalah lie detector memiliki urgensi dalam penggunaannya pada tahap penyidikan kasus tindak pidana pembunuhan berencana yang sulit untuk dipecahkan sebagai instrument untuk menggali keterangan tersangka guna mendapatkan persesuaian dengan alat bukti sehingga menghasilkan sebuah fakta yang sebenarnya dan kedudukan lie detector sebagai sarana pendukung pemeriksaan proses penyidikan, hasil print out lie detector ini berguna sebagai pelengkap berkas penyidikan yang dikuatkan oleh keterangan ahli psikologi forensik sehingga keterangan ahli dari hasil analisa gambar grafik dari print out pemeriksaan lie detector tersebut dapat menjadi alat bukti yang sah sebagaimana yang tercantum dalam Pasal 184 ayat (1) KUHAP, yakni sebagai alat bukti keterangan ahli.
\end{abstract}




\section{PENDAHULUAN}

\section{A. Latar Belakang Masalah.}

Teknologi merupakan penunjang kemajuan manusia dalam hampir setiap aspek kehidupan. Kemajuan ilmu pengetahuan dan teknologi (IPTEK) sebagai bagian integral pembangunan nasional harus ditujukan untuk menjadi landasan berbagai aspek dan meningkatkan kesejahteraan masyarakat secara berkelanjutan.

Tindak pidana merupakan kelakukan yang diancam dengan pidana, yang bersifat melawan hukum, yang berhubungan dengan kesalahan dan dilakukan oleh orang yang bertanggung jawab. ${ }^{1)}$

Perilaku menyimpang merupakan suatu ancaman terhadap norma-norma sosial yang mendasari kehidupan atau keteraturan sosial, serta dapat menimbulkan ketegangan individu maupun ketegangan-ketegangan sosial, dan merupakan ancaman yang potensial bagi berlangsungnya ketertiban sosial. ${ }^{2)}$

Kejahatan adalah pelanggaran norma hukum yang patut ditafsirkan sebagai perbuatan yang merugikan, menjengkelkan dan tidak boleh dibiarkan. Ketidak puasan terhadap kondisi dan keadaan membuat meningkatnya kualitas dan kuantitas kejahatan, apabila kejahatan meningkat maka berbagai macam cara dan motif akan digunakan untuk melancarkan kejahatan tersebut. ${ }^{3)}$

Hukum hadir sebagai tonggak untuk menanggulangi dan juga meminimalisir kejahatan yang timbul dari stigma negatif seorang pelaku tindak pidana.

Kepentingan penegakan hukum (law enforcement) yang sesuai dengan prosedur (due process of law) tentunya harus ada suatu pengawasan berupa aturan yang menjadi payung hukum terselenggaranya penegakan hukum yang benar dan terhindar dari suatu kesewenang-wenangan aparat penegak hukum terhadap subjek yang sedang menghadapi proses hukum guna untuk membatasi kekuasaan negara dalam bertindak terhadap setiap warga masyarakat yang terlibat dalam proses peradilan.

Keberadaan hukum acara pidana dimaksudkan untuk melindungi masyarakat dari kesewenang-wenangan penguasa. Fungsi hukum acara pidana adalah untuk membatasi kekuasaan negara dalam bertindak terhadap setiap warga masyarakat yang terlibat dalam proses peradilan. Sistem pembuktian yang dianut KUHAP adalah sistem pembuktian menurut Undang-undang secara negatif (negatief wetelijk stelsel). Sistem pembuktian negatif diperkuat oleh prinsip kebebasan kekuasaan kehakiman. ${ }^{4)}$

Proses penegakan hukum membutuhkan adanya keterpaduan sistem peradilan pidana (intergrated criminal justice system). Menurut Muladi, sistem peradilan pidana sesuai dengan makna dan ruang lingkup sistem dapat bersifat phisik dalam arti sinkronisasi struktural (structural syncronization) dalam arti keselarasan mekanisme administrasi peradilan pidana, dapat pula bersifat substansial (substancial syncronization) dalam kaitannya dengan hukum positif yang tentunya telah berlaku di Negara Indonesia, dan

1) Sofjan Sastrawidjaya, Hukum Pidana-Asas Hukum Pidana sampai dengan Alasan Peniadaan Pidana, Armico Bandung, 1995, hlm 113

2) Heru Permana, Politik Kriminal, Universitas Atmajaya, Yogyakarta, 2007, hlm 11.

3) Haikal Kurniawan, Penggunaan Metode Sketsa Wajah dalam Menemukan Pelaku Tindak Pidana, Universitas Muhammadiyah, Surakarta, 2008, hlm 1.

4) Romli Atmasasmita, Kapita Selekta Hukum Pidana dan Kriminolog, Mandar Maju Bandung. 1995, hlm 106. 
dapat pula bersifat kultural (cultural syncronization) dalam arti menghayati pandangan, sikap, dan falsafah yang secara menyeluruh mendasari jalannya sistem peradilan pidana. ${ }^{5)}$

Undang-Undang Nomor 8 Tahun 1981 tentang Kitab Undang-Undang Hukum Acara Pidana (KUHAP) mengatur tentang tahapan sistem peradilan pidana, salah satunya adalah proses penyidikan sebagaimana yang dicantumkan dalam Pasal 1 angka 2 Kitab Undang-Undang Hukum Acara Pidana yang merupakan serangkaian tindakan penyidik untuk mencari dan mengumpulkan alat bukti, guna menemukan tersangkanya. Tentunya hal ini juga sebagai suatu proses untuk membuat terang suatu perkara pidana yang terjadi.

Ironisnya dalam proses penyidikan seringkali terjadi suatu pemberian keterangan dan data yang bersifat manipulatif guna untuk menutupi fakta dan kejadian yang sebenarnya.

Kasus pembunuhan berencana, merupakan sebuah kasus yang masuk dalam kategori tindak pidana berat mengingat sangsi yang dijatuhkan bagi pelaku tindak pidana pembunuhan berencana maksimal adalah pidana mati, hal ini tertuang dalam Pasal 340 KUHP. Oleh sebab itu penyidik dalam melakukan proses penyidikan tentulah harus berhati-hati dalam menangani kasus tersebut.

Inkonsistensi dari jawaban tersangka / saksi dalam pembuatan BAP (Berita Acara Pemeriksaan) dalam proses penyidikan sering kali terjadi, kesulitan untuk menemukan keterangan yang sebenarnya dan mendapatkan alat bukti untuk membantu menguatkan berita acara pemeriksaan (BAP) yang telah dibuat oleh penyidik karena keterangan tersangka yang selalu berubah-ubah, oleh karena itu penggunaan sarana alternatif untuk mendukung proses penyidikan digunakan penyidik untuk membantu proses pengungkapan perkara dalam tindak pidana. Lie detector hadir sebagai suatu wujud dari perkembangan Ilmu Pengetahuan dan Teknologi yang dapat menjadi sarana pendukung penyidik dalam membuat terang suatu perkara.

Lie detector merupakan salah satu bentuk pemeriksaan bidang fisika forensik dari proses penyidikan, dengan melakukan identifikasi melalui bukti-bukti fisik, pemeriksaan laboratorium akan membantu terungkapnya suatu tindak pidana yang telah terjadi.

Berdasarkan Pasal 9 ayat (1) Peraturan Kapolri Nomor 10 Tahun 2009 tentang Tatacara dan Persyaratan Permintaan Pemeriksaan Teknis Kriminalistik Tempat Kejadian Perkara dan Laboratoris Kriminalistik Barang Bukti kepada Laboratorium Forensik Kepolisian Negara Republik Indonesia yang berbunyi:

"Pemeriksaan laboratoris kriminalistik barang bukti dapat dipenuhi berdasarkan permintaan tertulis:

a. Penyidik POLRI;

b. PPNS;

c. Kejaksaan;

d. Pengadilan;

e. POM TNI; dan

f. Instansi lain sesuai dengan lingkup kewenangannya."

Penelitian ini mengangkat kasus pembunuhan anak yang duduk di kelas tiga sekolah dasar bernama Angeline oleh ibu angkatnya sendiri. Pemeriksaan penyidikan dengan menggunakan lie detector terhadap Margriet Megawe mampu menambah keyakinan penyidik untuk menetapkannya sebagai tersangka utama kasus pembunuhan berencana terhadap Angeline. Margriet Megawe dijatuhi vonis seumur hidup karena telah terbukti secara sah dan meyakinkan

5) Muladi, Kapita Selekta Sistem Peradilan Pidana, Universitas Diponegoro, Semarang, 1995, hlm. 13. 
melakukan tindak pidana pembunuhan berencana dan melakukan eksploitasi pada anak juga menelantarkan anak dan perlakuan diskriminasi terhadap anak sebagaimana yang tertuang dalam putusan PN Denpasar Nomor 863/Pid.B/2015/PN Dps Tahun 2016.

Kasus lainnya yang menggunakan lie detector adalah Jessica Kumala Wongso yang kini menjadi terpidana kasus pembunuhan berencana terhadap korbannya Wayan Mirna Salihin yang dikabarkan meninggal dunia sesaat setelah dirinya menenggak tiga gram racun sianida yang terkandung dalam satu gelas Vietnam Ice Coffee, pada saat Mirna, Jessica dan Hani mengadakan sebuah pertemuan di Olivier Caffe Jakarta. Pada akhirnya Putusan PN Jakarta Pusat Nomor 777/Pid.B/2016/PN.JKT.PST Tahun 2016 hakim menjatuhkan vonis terhadap Jessica Kumala Wongso dengan 20 tahun penjara karena telah terbukti secara sah dan meyakinkan telah melakukan suatu tindak pidana pembunuhan berencana sebagaimana yang dicantumkan dalam Pasal 340 KUHP.

\section{B. Identifikasi Masalah.}

1. Apakah yang menjadi urgensi penggunaan lie detector (alat pendeteksi kebohongan) dalam tahap proses penyidikan terhadap tindak pidana pembunuhan berencana?

2. Bagaimanakah kedudukan lie detector (alat pendeteksi kebohongan) dihubungkan dengan Undang-Undang Nomor 8 Tahun 1981 tentang Kitab Undang-Undang Hukum Acara Pidana?

\section{TINJAUAN PUSTAKA}

Hukum pidana adalah bagian dari keseluruhan hukum yang berlaku dari suatu negara, yang mengadakan dasar-dasar dan aturan-aturan untuk: ${ }^{6}$

a. Menentukan perbuatan-perbuatan mana yang tidak boleh dilakukan, yang dilarang dan disertai ancaman atau sanksi yang berupa pidana tertentu bagi barang siapa yang melanggar larangan tersebut.

b. Menentukan kapan dan dalam hal-hal apa kepada mereka yang telah melanggar laranganlarangan itu dapat dikenakan atau dijatuhi pidana sebagaimana yang telah diancamkan.

c. Menentukan bagaimana pengenaan pidana itu dapat dilaksanakan apabila ada orang yang disangka telah melanggar larangan tersebut.

Pengertian hukum pidana yang telah disebutkan diatas dalam ke 1) adalah mengenai "perbuatan pidana" (criminal act). Sedang yang disebut dalam ke 2) adalah mengenai "pertanggungjawaban hukum pidana" (criminal liability atau criminal responsibility). Yang disebut dalam ke 1) dan ke 2) merupakan "hukum pidana materil" (substantive criminal law), oleh karena mengenai isi hukum pidananya sendiri. Yang disebut dalam ke 3) adalah mengenai bagaimana caranya atau prosedurnya untuk menuntut ke depan pengadilan orang-orang yang disangka melakukan perbuatan pidana, oleh karena itu dibagian ke 3) ini dinamakan "hukum pidana formil" atau "hukum acara pidana" (criminal procedure). Lazimnya yang disebut dengan hukum pidana saja adalah "hukum pidana materiil".")

Kitab Undang-Undang Hukum Pidana sebagai hukum materiil menjelaskan Pembunuhan yang dilakukan dengan rencana (moord), boleh dikatakan ini sebagai pembunuhan berencana

6) Sofjan Sastrawidjaya, Hukum Pidana-Asas Hukum Pidana sampai dengan Alasan Peniadaan Pidana, Armico Bandung, 1995, hlm 12.

7) Ibid, hlm 13. 
sebagaimana yang dikemukakan dalam Pasal 338 KUHP atau yang disebut dengan pembunuhan biasa (doodslag) akan tetapi dilakukan dengan direncanakan terlebih dahulu. Direncanakan terlebih dahulu (voor bedachte rade) = antara timbulnya maksud untuk membunuh dengan perencanaannya masih ada tempo bagi si pembuat untuk dengan tenang memikirkannya misalnya dengan cara bagaimanakah pembunuhan itu akan dilakukan. Tempo ini tidak terlalu sempit akan tetapi tidak juga terlalu lama, yang penting apakah di dalam tempoh itu si pembuat dengan tenang masih dapat berpikir, yang sebenarnya ia masih ada kesempatan untuk membatalkan niatnya akan membunuh itu, tetapi tidak ia gunakan. Pembunuhan dengan menggunakan racun hampir semua adalah moord.

Tujuan hukum pidana itu ialah untuk memenuhi rasa keadilan. ${ }^{8)}$ Tirta Amidjaja menyatakan bahwa tujuan dari hukum pidana ialah untuk melindungi masyarakat. ${ }^{9)}$ E.Y. Kanter dan S.R. Siantuari menyatakan bahwa tujuan hukum pidana itu adalah untuk melindungi kepentingan orang perseorangan (individu) atau hak-hak asasi manusia dan melindungi kepentingan-kepentingan masyarakat dan negara dengan pertimbangan yang serasi dengan kejahatan / tindakan tercela dari satu pihak dan tindakan penguasa yang sewenang-wenang di lain pihak. ${ }^{10)}$

Hukum pidana dalam kaitannya dengan penegakan hukum itu sendiri dipengaruhi oleh beberapa faktor yang saling berkaitan, faktor itu adalah: hukumnya itu sendiri yang dimaksud adalah peraturan yang mengaturnya, pihak yang membentuk hukum dan menerapkan hukum, sarana atau fasilitas yang mendukung penegakan hukum dan faktor kebudayaan sebagai hasil karya, cipta dan rasa yang didasarkan pada karsa manusia di dalam pergaulan hidup. Dimana dalam sebuah Negara hukum, hukum itu sendiri merupakan sarana kontrol sosial dan untuk menjaga stabilitas (law as social control and social engineering). Selain itu fungsi hukum dalam sebuah Negara hukum yakni sebagai sarana pembaharuan atau perubahan di dalam masyarakat yang dalam aplikasinya hukum bergerak mengikuti masyarakat sesuai dengan perubahan dinamika dan kondisi kehidupan, sebagaimana istilah yang diketahui bahwa Hukum untuk Manusia, bukan Manusia untuk Hukum. ${ }^{11)}$

Penegakan hukum sebagai suatu sarana untuk mencapai prinsip tujuan hukum yakni keadilan, kepastian dan kemanfaatan yang sesuai dengan cita hukum bangsa dan negara Indonesia sebagaimana yang terkandung dalam Undang-Undang Dasar Negara Republik Indonesia Tahun 1945 untuk membangun negara yang merdeka, bersatu, bedaulat adil dan makmur. Cita hukum tersebut adalah Pancasila. Konsep Negara hukum pancasila artinya suatu sistem hukum yang didirikan berdasarkan asas-asas dan norma yang digali dari nilai-nilai kehidupan yang berkembang dalam masyarakat Indonesia.

Proses penegakan hukum membutuhkan adanya keterpaduan sistem peradilan pidana (intergrated criminal justice system). Menurut Muladi, sistem peradilan pidana sesuai dengan makna dan ruang lingkup sistem dapat bersifat phisik dalam arti sinkronisasi struktural (structural syncronization) dalam arti keselarasan mekanisme administrasi peradilan pidana, dapat pula bersifat substansial (substancial syncronization) dalam kaitannya dengan hukum positif yang tentunya telah berlaku di Negara Indonesia, dan

\footnotetext{
8) Ibid, hlm 21 .

9) Ibid.

10) Ibid, hlm 22.

${ }^{11)}$ www.google.co.id/amp/s/t1g3rs.wordpress.com/2008/12/30/faktor-faktor penegakan-hukum-2/amp/, diakses pada hari Kamis, 21-Desember-2017, pukul 15.47. -yang-mempengaruhi-
} 
dapat pula bersifat kultural (cultural syncronization) dalam arti menghayati pandangan, sikap, dan falsafah yang secara menyeluruh mendasari jalannya sistem peradilan pidana. ${ }^{12)}$

Sistem peradilan pidana terpadu itu merupakan sistem penegakan hukum yang terdiri dari subsistem terdepan yaitu kepolisian hingga akhir (penjatuhan pidana, lembaga pemasyarakatan) untuk menanggulangi kejahatan dalam hubungan vertikal dan horizontal sesuai dengan undangUndang dan peraturan yang berlaku untuk menjaga keseimbangan perlindungan dan kepentingan negara, masyarakat, individu dan kepentingan korban atau pelaku tindak pidana itu sendiri.

Sistem peradilan pidana terpadu itu maka terbentuk suatu peradilan pidana sebagai tempat pengujian hak-hak asasi manusia yang memiliki ciri khusus yaitu subsitem yang memiliki kelembagaan sendiri-sediri dan memiliki tugas pokok dan fungsi masing-masing yang harus bekerjasama secara terpadu untuk law enforcement (penegakan hukum) yang due process of law (proses yang sesuai peraturan yang berlaku). Peradilan pidana memiliki serangkaian tahapan mulai dari penyelidikan, penyidikan, penangkapan, penahanan, pemeriksaan, persidangan di pengadilan hingga tahap pemidanaan yang merupakan serangkaian yang sangat kompleks dan tidak jarang dalam proses penegakan hukumnya banyak para pencari keadilan khususnya masyarakat awam yang kurang memahami proses penegakan hukum sehingga merasa ketakutan. Hal tersebut juga tidak bisa dipungkiri sebagai dampak persepsi yang diambil dari beberapa media massa baik cetak maupun elektronik.

Perwujudan dari proses penegakan hukum di Negara Indonesia maka dibentuklah Undang-Undang Nomor 8 Tahun 1981 tentang Kitab Undang-Undang Hukum Acara pidana sebagai suatu hukum formil yang mengatur proses dan tatacara pelaksanaan penegakan hukum dan penanganan perkara pidana yang bertujuan untuk menghindari tindakan yang sewenangwenang oleh aparat penegak hukum.

Pembuktian perkara pidana merupakan titik sentral yang terpenting dalam proses persidangan, peranan pembuktian untuk menentukan seseorang yang diduga bersalah dalam melakukan suatu tindak pidana, pembuktian terhadap kesalahan terdakwa yang didakwakan oleh Jaksa Penuntut Umum (JPU) menentukan hasil putusan hakim dalam akhir proses persidangan di pengadilan. Jika hasil pembuktian dari alat-alat bukti yang ditentukan oleh Undang-Undang tidak cukup maka terdakwa dibebaskan, jika pembuktian menggunakan alat bukti yang ditentukan oleh Undang-Undang tersebut cukup maka sebaliknya, terdakwa dinyatakan bersalah dan dapat dijatuhi pidana. Pembuktian dengan perbuatan yang dilakukan dengan unsur-unsur yang terdapat dalam rumusan delik merupakan inti dari proses pembuktian. ${ }^{13)}$

Undang-Undang Nomor 8 Tahun 1981 tentang Kitab Undang-Undang Hukum Acara Pidana (KUHAP) menganut teori pembuktian negatif. Pasal 183 KUHAP menyatakan bahwa hakim tidak boleh menjatuhkan pidana terhadap terdakwa, kecuali dengan sekurang-kurangnya 2 alat bukti yang sah dan keyakinan hakim bahwa suatu tindak pidana benar-benar terjadi dan terdakwalah yang bersalah melakukannya.

Proses perkara pidana dimulai dari subsistem yang terdepan yakni kepolisian, memiliki tahapan yang sistematis dalam menegakan hukum yang due process of law, hingga sampai dalam tahapan penjatuhan pidana melalui Lembaga Permasyarakatan. Tahapan tersebut dimulai dari tahap penyelidikan, penyidikan, penuntutan, persidangan hingga sampai dalam tahap putusan yang dijatuhkan oleh hakim di pengadilan.

12) Muladi, Kapita Selekta Sistem Peradilan Pidana, Universitas Diponegoro, Semarang, 1995, hlm. 13.

13) Hartono, Penyidikan dan Penegakan Hukum Pidana melalui Pendekatan Hukum Progresif, Sinar Gratika, Jakarta, 2012, hlm 65 . 
Kitab Undang-Undang Hukum Acara Pidana Indonesia, dalam BAB I Ketentuan Umum Pasal 1 angka 2 menyatakan penyidikan adalah serangkaian tindakan penyidik dalam hal dan menurut cara yang diatur dalam Undang-Undang, untuk mencari serta mengumpulkan bukti yang dengan bukti itu dapat membuat terang tentang tindak pidana yang terjadi dan guna menemukan tersangkanya.

Penyidik melakukan pemeriksaan dengan memanfaatkan fasilitas yang dimiliki oleh kepolisian Negara republik Indonesia melalui pusat laboratorium forensik (Puslabfor). Ilmu forensik dibutuhkan oleh Kepolisian Negara Republik Indonesia (Polri) untuk membantu proses penyidikan melalui pemeriksaan-pemeriksaan terhadap bukti-bukti dari suatu tindak pidana seperti pemeriksaan terhadap korban, tersangka, saksi atau alat dan barang bukti lainnya. Pihak yang berwenang untuk mengadakan pemeriksaan forensik yaitu Laboratorium Forensik.

Salah satu bentuk pemeriksaan ilmu forensik yaitu dengan melaksanakan pemeriksaan dan identifikasi terhadap bukti-bukti fisik yang dapat menyulitkan tersangka untuk menyembunyikan keterangan yang sebenarnya. Hal itu dilakukan karena barang bukti (buktibukti fisik) tidak dapat berbohong namun alat bukti seperti keterangan saksi, keterangan ahli dan keterangan terdakwa bisa saja berbohong atau disuruh berbohong. Contohnya pemeriksaan saksi atau tersangka dengan menggunakan alat pendeteksi kebohongan (lie detector) atau yang biasa dikenal dengan poligraf.

\section{PEMBAHASAN}

\section{Urgensi Penggunaan Lie Detector (Alat Pendeteksi Kebohongan) dalam Tahap Proses Penyidikan terhadap Tindak Pidana Pembunuhan Berencana.}

Kasus yang penulis angkat dalam penelitian ini terkait dengan pembunuhan berencana yang dilakukan oleh tersangka utama yakni ibu angkat Angeline bernama Margriet Megawe, yang menjalani proses penyidikan dengan menggunakan lie detector, ada beberapa hal yang penulis analisa terkait dengan hasil pemeriksaan menggunakan lie detector ini.

Pertama saat Margriet dikonfrontasi mengenai adanya suatu gundukan tanah yang didalamnya terkubur jasad Angeline dekat kandang ayam halaman belakang rumahnya, Margriet menyatakan bahwa ia tidak mengetahui adanya tanah yang digali dan berbentuk gundukan itu. Lie detector mendeteksi adanya suatu kebohongan dalam pernyataan Margriet tersebut.

Kedua pada saat ditanya mengenai peristiwa kematian Angeline, Margriet menampik bahwa ia telah membunuh, mencubit dan menjambak rambut Angeline. Pemeriksaan lie detector dengan menggunakan 3 sensor utama, yakni pneumograph sensor, skin resistant sensor dan blood pressure of cup menggambarkan frekuensi garis turun dan menaik yang sangat signifikan kedalam sebuah gambar grafik hasil dari deteksi kebohongan subjek yang diperiksa. Akhirnya Margriet Megawe ditetapkan sebagai tersangka utama dari meninggalnya Angeline. Berdasarkan Putusan PN Denpasar Nomor 863/Pid.B/2015/PN Dps Tahun 2016 Margriet Christina Megawe alias Teli, hakim menjatuhkan hukuman seumur hidup terhadap Margriet Megawe karena telah terbukti secara sah dan meyakinkan bersalah melakukan tindak pidana Pembunuhan berencana dan melakukan exploitasi terhadap anak dan menelantarkan anak dan perlakuan diskriminasi terhadap anak.

Kasus lainnya yakni Jessica Kumala Wongso diperiksa menggunakan lie detector pada tahap proses penyidikan, ada tiga hal yang penulis temukan mengenai pemeriksaan penyidikan yang dilakukan oleh penyidik forensik. 
Pertama pada saat Jessica dikonfrontasi mengenai keberadaan es kopi Vietnam, Jessica mengatakan bahwa pada saat ia mengetahui bahwa ada waiters (pelayan caffe) yang datang dengan membawa satu gelas es kopi Vietnam Jessica mengatakan "Saya assume itu kopi", kata assume dalam Bahasa Inggris ini apabila diterjemahkan kedalam Bahasa Indonesia berarti "memperkirakan", artinya Jessica mengetahui itu kopi, atau Jessica curiga bahwa itu bukan kopi. Dalam beberapa hal sederhana tersebut kalimat yang diutarakan Jessica pada saat proses pemeriksaan menjadi suatu analisa baru dalam kaitannya dengan hasil lie detector.

Kedua pada saat Jessica dikonfrontasi mengenai kandungan tiga gram racun sianida yang bersifat korosif, mematikan dan berbahaya tertuang dalam es kopi Vietnam, Jessica tidak mengatakan bahwa ia menaruhnya, namun ekspresi wajah Jessica mencerminkan seseorang yang sedang tersenyum pada (00:00:45- $680 \mathrm{~F}, 681 \mathrm{~F}, 682 \mathrm{~F})$.

Ketiga pada saat memberikan keterangannya, terdapat beberapa kalimat yang tidak sinkron sebanyak tiga kali, seperti kata "gara-gara" menjadi "gagara", hal ini menguatkan grafik deteksi kebohongan dalam kalimat yang diungkapkan Jessica.

Ketika seseorang berbohong dia akan menunjukan beberapa kalimat verbal yang salah yang diucapkan berulang kali sebagai suatu wujud koreksi dari akibat ketidak- sinkronan antara pikiran dan fakta dalam menumpahkannya menjadi sebuah bentuk kalimat. Hal ini juga dapat menyebabkan ketidak-sinkronan antara emosi dari subjek yang diperiksa sehingga menghasilkan beberapa pergerakan dada yang terdeteksi oleh sensor pneumograph, tekanan darah yang terdeteksi oleh sensor blood pressure cuff dan detak jantung yang meningkat sangat signifikan.

Hakim Pengadilan Negeri Jakarta Pusat menjatuhkan hukuman selama 20 tahun penjara karena Terdakwa Jessica Kumala Wongso alias Jess telah terbukti secara sah dan meyakinkan bersalah melakukan tindak pidana Pembunuhan berencana.

Pembunuhan berencana diatur dalam Pasal 340 KUHP berbunyi, barang siapa sengaja dan dengan rencana terlebih dahulu merampas nyawa orang lain, diancam dengan pidana mati atau pidana penjara seumur hidup atau selama waktu tertentu, paling lama 20 tahun sebagaimana yang tercantum dalam Putusan PN Jakarta Pusat Nomor 777/Pid.B/2016/PN.JKT.PST Tahun 2016.

Hasil analisa mengenai penggunaan lie detector dari kasus yang penulis paparkan diatas, bahwa lie detector dalam peranannya sebagai sarana pendukung proses pemeriksaan penyidikan memiliki urgensi dan peranan yang penting untuk mengungkap suatu tindak pidana, karena dapat menambah keyakinan penyidik tentang tersangka kuat dari kasus tindak pidana pembunuhan berencana yang terjadi. Dimana hasil lie detector ini akan dikaitkan dengan alat bukti yang telah ada sebelumnya, guna mendapatkan suatu persesuaian fakta yang sebenarnya. Jadi lie detector memiliki urgensi dalam proses penyidikan terhadap kasus tindak pidana pembunuhan berencana, yakni:

a. Lie detector sebagai instrument pendukung dalam pemeriksaan tersangka dan saksi, yang diminta penyidik melalui Pusat Laboratorium Forensik (Puslabfor) untuk memudahkan penyidik dalam melakukan kasus pembunuhan berencana yang dilakukan Jessica dan dalam kasus kainnya yakni kematian dari Angeline.

b. Lie detector digunakan sebagai alat bantu pemeriksaan dalam kasus yang sulit untuk dipecahkan, lie detector menjadi alat bantu untuk menemukan fakta sebenarnya.

C. Inkonsistensi atau keterangan dari saksi atau tersangka terhadap kasus pembunuhan berencana diatas selalu berubah-ubah, ini menjadi hambatan penyidik dalam memecahkan suatu perkara pidana, hasil dari lie detector dapat menjadi bukti penunjang dari pertimbangan penyidik dalam mengkaitkan bukti dan fakta yang ada. 
d. Lie detector digunakan guna untuk membuat terang suatu perkara pidana pembunuhan berencana dengan cara mendeteksi dan mengetahui kebenaran dari keterangan yang diungkapkan saksi atau tersangka.

e. Lie detector sebagai instrument untuk menggali keterangan saksi atau tersangka guna untuk mendapatkan persesuaian dengan alat bukti sehingga menghasilkan sebuah fakta yang sebenarnya.

\section{Kedudukan Lie Detector (Alat Pendeteksi Kebohongan) Dihubungkan dengan Undang- Undang Nomor 8 Tahun 1981 tentang Kitab Undang-Undang Hukum Acara Pidana.}

Lie detector dalam peranannya sebagai alat bantu penyidikan dalam pengungkapan kasus yang pelik dan sulit untuk dipecahkan telah banyak membantu menambah keyakinan penyidik guna menemukan tersangkanya. Terutama dalam kasus pembunuhan berencana.

Lie detector merupakan salah satu pemeriksaan bidang fisika forensik dengan menggunakan scientific investigation. Hal ini dirumuskan dalam Pasal 9 ayat (2) Peraturan Kapolri Nomor 10 Tahun 2009 tentang Tatacara dan Persyaratan Permintaan Pemeriksaan Teknis Kriminalistik Tempat Kejadian Perkara dan Laboratoris Kriminalistik Barang Bukti kepada Laboratorium Forensik Kepolisian Negara RI yaitu jenis barangbukti yang dapat dilakukan Labfor Polri meliputi pemeriksaan bidang fisika forensik.

Pemeriksaan dengan menggunakan lie detector dilakukan penyidik dalam kasus Angeline dan Jessica Kumala Wongso atas permintaan penyidik terhadap Pusat Laboratorium Forensik (Puslabfor) dalam menangani pemeriksaan kasus tersebut, karena kasus diatas dianggap sulit untuk dipecahkan.

Penyidik menggunakan lie detector tersebut sebagai instrument sarana atau pra sarana dalam penegakan hukum yang tentunya dapat mempengaruhi efisiensi dalam penegakan hukum dalam menemukan bukti kuat dari hasil penyidikan terhadap kasus kematian Angeline dan kematian Mirna. Dilakukan dengan cara memasangkan sensor ke bagian tubuh saksi atau tersangka dalam kasus tersebut, mencatat setiap pergerakan yang dihasilkan dari gejala tubuh subjek yang diperiksa melalui sensor pneumograph dengan fungsinya untuk mengukur tekanan dada subjek yang diperiksa, sensor blood pressure of cup berfungsi untuk mengukur tekanan darah dan sensor skin resistant berfungsi untuk mengukur jumlah keringat yang keluar dari jarijari subjek yang diperiksa.

Kedudukan lie detector memiliki keterkaitan dengan Pasal 184 ayat (1) KUHAP. Yakni print out (kertas yang dicetak) dari hasil pemeriksaan menggunakan lie detector yang dilakukan terhadap saksi atau tersangka dapat dijadikan sebagai pelengkap (tambahan) berkas penyidikan yang diperkuat oleh keterangan ahli psikologi forensik yang menjelaskan tentang isi dari hasil analisa gambar grafik berbentuk print out. Jadi kedudukan Lie detector dalam Kitab Undangundang Hukum Acara Pidana (KUHAP), bukanlah sebagai alat bukti. Namun hasil print out dari lie detector yang dianalisa oleh ahli psikologi forensik akan menjadi keterangan ahli dalam persidangan. Keterangan ahli dalam persidangan dapat dijadikan sebagau alat bukti keterangan ahli yang sah, sebagaimana yang tercantum dalam Pasal 184 ayat (1) KUHAP. 


\section{PENUTUP}

\section{Kesimpulan}

Penggunaan lie detector sebagai alat pendukung proses pemeriksaan dalam tahap penyidikan memiliki urgensi dalam mengungkap kasus tindak pidana pembunuhan berencana, hasil lie detector ini akan dikaitkan dengan alat bukti yang telah ada sebelumnya, guna mendapatkan suatu persesuaian fakta yang sebenarnya.

Kedudukan lie detector memiliki keterkaitan dengan Pasal 184 ayat (1) KUHAP. Yakni print out (kertas yang dicetak) dari hasil pemeriksaan menggunakan lie detector yang dilakukan terhadap saksi atau tersangka dapat dijadikan sebagai pelengkap (tambahan) berkas penyidikan yang diperkuat oleh keterangan ahli psikologi forensik yang menjelaskan tentang isi dari hasil analisa gambar grafik berbentuk print out. Jadi kedudukan Lie detector dalam Kitab Undangundang Hukum Acara Pidana (KUHAP), bukanlah sebagai alat bukti. Namun hasil print out dari lie detector yang dianalisa oleh ahli psikologi forensik akan menjadi keterangan ahli dalam persidangan. Keterangan ahli dalam persidangan dapat dijadikan sebagai alat bukti keterangan ahli yang sah, sebagaimana yang tercantum dalam Pasal 184 ayat (1) KUHAP.

\section{Saran}

Lie detector sebagai sarana pendukung proses pemeriksaan yang dilakukan penyidik merupakan sebuah langkah yang positif, sebagai instrument pendukung penyidikan dalam kasus yang sulit untuk dipecahkan sesuai dengan urgensinya, akan tetapi dalam penggunaannya masih banyak hambatan yang terjadi. Oleh sebab itu dalam penggunaan lie detector, penyidik psikologi forensik yang memeriksa subjek, haruslah memastikan kondisi fisik subjek yang diperiksa dalam keadaan sehat, tidak dalam keadaan uder pressure supaya sistem akurasi hasil detektor ini dapat diperhitungkan, ahli pemeriksa yang menggunakan lie detector haruslah memenuhi SOP (standard operational prosedur) pemeriksaan lie detector, subjek harus dilengkapi dengan keterangan sebelum pemeriksaan juga eningkatan sarana dan prasarana terkait lie detector sebagai alat pendukung pemeriksaan haruslah lebih ditingkatkan.

Lie detector dalam fungsinya sebagai sarana pendukung proses penyidikan tentunya memiliki kedudukan yang dapat mempengaruhi proses pembuktian di persidangan guna mempengaruhi keyakinan hakim terhadap bukti kuat dari adanya suatu tindak pidana, mengingat bahwa pembuktian merupakan titik sentral dalam persidangan. Oleh sebab itu penyempurnaan terhadap penggunaan lie detector harus terus dilakukan sebagai salah satu wujud dari pembaharuan penegakan hukum di Indonesia, penyempurnaan tersebut dapat dilakukan terhadap tenaga yang berpendidikan dalam menggunakan tekhnologi pendukung pemeriksaan dengan menggunakan lie detector, pengetahuan dan wawasan penyidik psikologi forensik yang menunjang berjalannya pemeriksaan sesuai dengan SOP, para ahli untuk membaca hasil print out lie detector harus ditunjang dengan pengalaman dan pengetahuan secara detail dalam memberikan keterangan sesuai dengan hasil dari penggunaan lie detector itu, integrasi antar lembaga penegak hukum agar penggunaan lie detector sebagai alat pemeriksaan penyidikan dapat berjalan secara optimal, efektif dan efisien dalam proses penegakan hukum di negara Indonesia. 


\section{DAFTAR PUSTAKA}

Sofjan Sastrawidjaya, Hukum Pidana-Asas Hukum Pidana sampai dengan Alasan Peniadaan Pidana, Armico Bandung, 1995,

Hartono, Penyidikan dan Penegakan Hukum Pidana melalui Pendekatan Hukum Progresif, Sinar Gratika, Jakarta, 2012,

Heru Permana, Politik Kriminal, Universitas Atmajaya, Yogyakarta, 2007,

Haikal Kurniawan, Penggunaan Metode Sketsa Wajah dalam Menemukan Pelaku Tindak Pidana, Universitas Muhammadiyah, Surakarta, 2008,

Romli Atmasasmita, Kapita Selekta Hukum Pidana dan Kriminolog, Mandar Maju Bandung. 1995 ,

Muladi, Kapita Selekta Sistem Peradilan Pidana, Universitas Diponegoro, Semarang, 1995

Sofjan Sastrawidjaya, Hukum Pidana-Asas Hukum Pidana sampai dengan Alasan Peniadaan Pidana, Armico Bandung, 1995,

www.google.co.id/amp/s/t1g3rs.wordpress.com/2008/12/30/faktor-faktor -yang-mempengaruhipenegakan-hukum-2/amp/, diakses pada hari Kamis, 21-Desember-2017, pukul 15.47. 